\title{
Menamai Sang Nama: Polemik Nama YHWH-Allah
}

\author{
Deflit Dujerslaim Lilo \\ Institut Agama Kristen Negeri Toraja \\ ddujerslilo@gmail.com
}

\begin{abstract}
The focus of this paper is about the polemic that occurred around the use of the names Yahweh and God in Christianity. The name Yahweh is claimed by The Sacred Name Movement as the only name of the LORD to be believed and mentioned by believers. Therefore, the purpose of this research is to examine this view and find out whether the mention of the name of God that used in both the Bible and worship is wrong and Christianity must re-use the name Yahweh. Using qualitative methods sourced from literature studies, authors make the critical but evaluative studies by examining hermeneutically and collecting data from various sources of literature. As a result, researcher concludes that Christianity is not antipathic to the use of the name Yahweh but stating that mentioning and using the name Yahweh will affect on the salvation of someone is an absurd assumption and a logical fallacy.
\end{abstract}

Keywords: God, the sacred name movement, tetragrammaton, Yudaism

\begin{abstract}
Abstrak-Fokus dari tulisan ini adalah mengenai polemik yang terjadi di seputar penggunaan nama Yahweh dan Allah dalam kekristenan. Nama Yahweh diklaim oleh kelompok Gerekan Nama Suci sebagai satu-satunya nama TUHAN yang harus diimani dan disebut oleh orang percaya. Karena itu, tujuan penelitian ini adalah untuk mengkaji pandangan tersebut dan menemukan apakah sebutan Allah yang digunakan baik di dalam Alkitab maupun ibadah adalah sebutan yang keliru dan dengan demikian kekristenan harus kembali menggunakan nama Yahweh. Menggunakan metode kualitatif yang bersumber dari studi literatur, penulis membuat kajian yang bersifat kritis namun evaluatif dengan meneliti secara hermeneutis maupun mengumpulkan data dari berbagai sumber kepustakaan. Hasilnya, peneliti menyimpulkan bahwa kekristenan tidak bersikap antipati terhadap penggunaan nama Yahweh tetapi dengan menyatakan bahwa menyebut dan menggunakan nama Yahweh akan memengaruhi keselamatan seseorang merupakan asumsi yang absurd dan cacat logika.
\end{abstract}

Kata Kunci: Allah, gerakan nama suci, tetragramaton, Yudaisme

\begin{tabular}{llll}
\hline Article History : & Received: 21-Juni-2020 Accepted: 29-Juni-2020
\end{tabular}

\section{Pendahuluan}

Saksi Yehuwa (Jehovah Witnesses) yang selanjutnya akan disingkat SY, telah sangat dikenal sebagai salah satu aliran kepercayaan dalam kekristenan. Dalam beberapa literatur, kelompok ini lebih diklasifikasikan sebagai sebuah bidat karena 
berbagai pandangannya yang dipandang sesat dan menyesatkan.1 Walaupun berbagai pandangan itu tidak akan dibahas secara mendetail -satu per satu- dalam tulisan ini namun konteks polemik nama YHWH memang tidak dapat disangkal akan berkaitan erat dengan salah satu inti pandangan aliran tersebut, yaitu penyakralan nama YHWH. Polemik ini memang tidak terlepas dari kemunculan sekte baru dalam agama Yahudi yaitu Yudaisme Mesianik. Pengaruh yang kuat dari Gerakan Yudaisme Mesianik mengenai pentingnya pembaruan dan pemulihan dalam tradisi Yahudi, ditujukan bagi orang-orang Yahudi yang telah percaya kepada Yesus.2

Yudaisme Mesianik (Messianic Judaism) adalah aliran yang berasal dari kalangan Yudaisme dan atau bangsa Yahudi yang percaya kepada Yesus Kristus namun tidak mengakui diri mereka sebagai gereja dan Kristen. Selain itu, kelompok ini juga tetap memegang teguh gaya hidup dan tata ibadat secara Yudais namun sesuai dengan ajaran Yesus yang diakui sebagai Mesias. Menurut Michael Shiffman kelompok ini adalah kelompok yang secara lahiriah merupakan keturunan Yahudi tetapi tidak menjalankan tradisi dari kaum rabinik. ${ }^{3}$ Senada dengan itu, David Stern berpendapat bahwa penganut sekte ini adalah orang Yahudi secara lahirian dan atau menjadi mualaf ke dalam agama Yahudi, namun tetap beriman dan mengakui Yesus dan keyahudian-Nya. ${ }^{4}$ John Fischer melangkah lebih jauh dengan berpendapat bahwa walaupun kelompok Yudaisme Mesianik sama dengan penganut agama Kristen pada umumnya yang mengakui Yesus dan Alkitab, akan tetapi mereka mengekspresikan iman, gaya hidup, dan model peribadatan sesuai dengan tata cara Yudaisme. ${ }^{5}$

Berdasarkan penjabaran di atas, paling tidak terdapat tiga karakteristik yang khas dari Yudaisme Mesianik, yaitu: 1) aliran ini didasarkan pada pergerakan spiritual oleh komunitas bangsa Yahudi dan agama Yudaisme, 2) penganut sekte ini selain tetap menerima Tanakh, mereka juga menerima kitab-kitab Perjanjian Baru dan beriman kepada Yesus sebagai Mesias, 3) iman kepada Yesus Kristus tidak lantas membuat mereka meninggalkan tradisi Yahudi terkhususnya di dalam hal-hal keagamaan. ${ }^{6}$

Gerakan ini mulai berkembang pesat di abad XIX dan memberikan pengaruh yang signifikan bagi kemunculan Gerakan Nama Suci (The Sacred Name Movement) ${ }^{7}$ yang

1Lihat seperti misalnya: Jan S. Aritonang, Berbagai Aliran di Dalam dan di Sekitar Gereja (Jakarta: BPK Gunung Mulia, 2008), 316-342

2Untuk penjelasan yang lebih lengkap, lihat: Herlianto, Gerakan Nama Suci - Nama Allah yang Dipermasalahkan (Jakarta: BPK Gunung Mulia, 2009), 6-7.

${ }^{3}$ Michael Shiffman, Return of the Remnant: the Rebirth of Messianic Judaism (Baltimore: Lederer Messianic Publishers, 1996), 23.

4David Stern, Messianic Jewish Manifesto (Maryland: Jewish New Testament Publications, 1991), 20.

5John Fischer, Why Messianic Judaism, dalam Enduring Paradoxs (Baltimore: Messianic Jewish Publishers, 2000), 8.

${ }^{6}$ Teguh Hindarto, "Messianic Judaism \& Sacred Name Movement: Fenomena Keagamaan Abad XX dan Tanggapan Kekristenan (Seri 1)," https://pijarpemikiran.blogspot.com (diakses 16 Juni 2020).

${ }^{7}$ Gerakan Nama Suci (The Sacred Name Movement) ini dalam beberapa diskursus ilmiah yang penulis amati, sering juga disebut dengan istilah Yahweisme untuk merujuk pada kelompok dan 
selanjutnya akan disingkat GNS, di Eropa dan Amerika. GNS inilah yang dinilai memberikan pengaruh yang cukup dominan bagi kemunculan dan sepak terjang SY. ${ }^{8}$ Berangkat dari paradigma yang sama, SY pun menekankan penulisan dan pengucapan nama YHWH secara konsisten. Berpendapat bahwa penerjemahan nama suci ke dalam bahasa-bahasa yang berbeda jelas merupakan sebuah kesalahan fatal. Otto memparafrasekannya dengan penekanan yang lebih radikal, "Penghilangan tersebut merupakan sebuah penghinaan terbesar kepada penulis ilahi Kitab Suci." ${ }^{9}$ Walaupun SY kemudian menerjemahkan dan melafalkan Tetragramaton itu dengan bunyi Jehovah, Yehovah, atau Yehuwa yang kemudian mempatenkan nama itu sebagai nama aliran pada tahun 1931. ${ }^{10}$ Di samping itu, anggapan bahwa Yesus dan para murid masih tetap menggunakan nama YHWH. Sebagai contoh, saat Yesus membaca Yesaya 61:1-2 dan ajarannya tentang nama itu dalam Yohanes 17:6; 26). ${ }^{11}$ Akan tetapi, dalam Kitab Suci Terjemahan Dunia Baru yang diterjemahkan oleh SY, nama Allah masih tetap digunakan. ${ }^{12}$

GNS sendiri, oleh beberapa teolog di-label-kan dengan sebutan "Yahweh-isme". Gerakan ini dimulai pada abad ke-19, sekitar tahun 1930-an di Amerika Serikat, di tengah pergolakan Perang Saudara (Civil War). ${ }^{13}$ Pelopor gerakan ini adalah salah satu perintis gerakan pemulihan nama Yahweh di kalangan gereja Church of God (COG) Seventh Day, yang bernama Clarence O. Dodd. Namun setelah keluar dari COG Seventh Day, Dodd mendirikan Assembly of Yahweh, yang getol menekankan keharusan untuk kembali kepada akar-akar yudaik. Penekanan ini meliputi pemulihan nama Yahweh dalam bahasa Ibrani, perayaan hari Sabat, dan hari-hari raya Yahudi. Jemaat Assembly of Yahweh berasal dari kalangan Kristen non-Yahudi yang kemudian terlibat secara aktif dalam The Sacred Name Movement/Gerakan Nama Suci.

Dalam artikelnya yang berjudul "Sacred Name Movement History", Organisasi Yahweh New Covenant Assemblies (YNCA) sebagai salah satu komunitas yang aktif dalam pergerakan pemulihan nama Yahweh, menjelaskan bahwa Gerakan Nama Suci mendasarkan pandangannya dari pernyataan dalam Amsal 30:4, "Siapakah yang naik ke sorga lalu turun? Siapakah yang telah mengumpulkan angin dalam genggamnya?

pemahaman mereka tentang penggunaan nama Yahweh. Penulis juga akan menggunakan istilah ini secara bergantian untuk menjelaskan pandangan ini.

8Ibid, 12.

${ }^{9}$ Oky Otto Otto, History of YHWH - Tantangan, Argumentasi, dan Pembuktian Sejarah Penggunaan Kata YHWH (Yogyakarta: ANDI, 2013), 3.

${ }^{10}$ Herlianto, Gerakan Nama Suci - Nama Allah yang Dipermasalahkan, x. Lihat juga sejarah berdiri dan berkembangnya Saksi Yehuwa di: Jan S. Aritonang, Ibid, 318-333.

11Watchtower Bible and Tract Society of New York Inc. International Bible Students Association, "Kitab Suci Terjemahan Dunia Baru, peny. New World Translation of The Holy Scriptures Indonesia" (New York: Watchtower Bible and Tract Society of New York Inc. International Bible Students Association, 1999): 2024, dikutip dalam Oky Otto Otto, Ibid, 3.

12Herlianto, Gerakan Nama Suci, Nama Allah yang Dipermasalahkan, 12.

13Ibid, xi. 
Siapakah yang telah membungkus air dengan kain? Siapakah yang telah menetapkan segala ujung bumi? Siapa namanya dan siapa nama anaknya? Engkau tentu tahu!"Ayat lain yang setara dengan itu adalah Wahyu 14:1, "Dan aku melihat: sesungguhnya, Anak Domba berdiri di bukit Sion dan bersama-sama dengan Dia seratus empat puluh empat ribu orang dan di dahi mereka tertulis nama-Nya dan nama Bapa-Nya."Atau dalam Yoel 2:32, "barangsiapa berseru kepada nama TUHAN (YHWH) akan diselamatkan...."

Fenomena The Sacred Name Movement tidak hanya berlangsung di Amerika dan Eropa, tetapi juga menyebar hingga Asia, termasuk Indonesia. Di Indonesia, gerakan ini lebih dikenal dengan sebutan Gerakan Nama Suci. Penganut gerakan ini tidak sedikit dan sebenarnya telah bergerak sejak tahun 1980-an. Menurut Herlianto:

Pada paruh kedua tahun 1980-an, beberapa mantan penganut Muslim yang menjadi Kristen merintis usaha penginjilan untuk menobatkan umat Islam melalui ceramah-ceramah, dan kemudian mendirikan Yayasan Nehemia (1987) untuk mendidik para penginjil. Dalam siar agamanya, secara pelan dan pasti yayasan ini memperkenalkan nama Yahweh dan menekankan kembalinya ibadat ke akar yudaik dengan membangkitkan kembali penggunaan bahasa Ibrani. ${ }^{14}$

Beberapa teolog di Indonesia juga sangat erat dikaitkan dengan Gerakan Nama Suci (GNS) ini, misalnya: Prof. Kristian Sugiarto, Pdt. Yakub Sulistyo S.Th. MA, lalu Pdt. Teguh Hindarto dari Nafiri Yahshua Ministry, dan dr. Suradi (akhir tahun 1990-an, dari Yayasan Nehemia). Tiga nama yang pertama dikenal sangat giat dalam pengajaran tentang keharusan menyebut nama Yahweh dan pada saat yang sama melarang penggunaan kata 'Allah'. Ajaran yang paling menimbulkan kontoversi dari gerakan ini adalah asumsi bahwa penyebutan nama YHWH yang benar dan tepat dapat memberikan dampak secara langsung pada keselamatan manusia. ${ }^{15}$

Sekelumit pandangan ini bukan saja berujung pada perdebatan yang panjang, tetapi juga perpecahan doktrinal di dalam gereja itu sendiri. Ada begitu banyak kelompok yang saling menyerang dan bertahan pada pandangan tentang penggunaan nama Allah dan Yahweh yang mulai memanas sejak awal tahun 2000-an dalam diskursus-diskursus teologi di berbagai tempat dan media termasuk di Indonesia.

Upaya sosialisasi untuk meniadakan penggunaan nama Allah dalam Alkitab dan setiap peribadatan orang Kristen dilakukan di gereja-gereja dan sekolah-sekolah berbasis teologi/keagamaan. Nama Allah kemudian diklaim sebagai nama sesembahan agama/kepercayaan tertentu yang non-Kristen sehingga haram untuk digunakan untuk menyebut dan menyembah-Nya. Hal ini tentu menempatkan orang Kristen dalam kebingunan dan keraguan.

Polemik ini sontak memunculkan sekumpulan pertanyaan yang rumit. Siapakah sesembahan kita? Apakah YHWH atau Allah? Apakah Allah berbeda dengan YHWH?

14Ibid,17.

15R. Clover, The Sacred Name, Jilid 1 (U.S.A.: Qadesh La YAHWEH Press, 2002), 223-229. 
Manakah nama yang benar dari sesembahan umat Kristen? Apakah harus mengganti kata Allah dalam Alkitab dengan Yahweh? Apakah pengucapan "nama" Yahweh memberikan dampak yang signifikan bagi keselamatan seseorang? Apakah LAI telah salah memakai nama Allah? Apakah dengan menyebut Allah dalam ibadah dan sebagainya, orang Kristen telah menghujat Yahweh? Lalu, sejauh mana paham-paham itu dapat dimengerti? Pertanyaan-pertanyaan ini akan dielaborasikan dan ditinjau dalam kemasan yang kritis dan evaluatif.

\section{Metode Penelitian}

Artikel ini menggunakan metode kualitatif yang bersumber pada penelitian kepustakaan.16 Untuk itu, penulis mengonsentrasikan penggunaan metode ini dengan menelaah berbagai literatur baik dari Alkitab itu sendiri khususnya Perjanjian Lama maupun buku-buku, jurnal, dan sumber-sumber lain yang telah membahas topik ini sebelumnya. Data yang diperoleh kemudian disajikan secara deskriptif dengan memberikan berbagai ulasan yang kritis dan evaluatif. Penulis juga akan memberikan penilaian dari sisi ilmu logika terhadap pandangan dari Gerakan Nama Suci yang merupakan pengagung nama Yahweh. Oleh sebab itu, tulisan ini tentunya bersifat apologetis di mana satu sisi berupaya mempertahankan pengajaran yang benar dan tepat namun di sisi lain juga menyerang pandangan lawan yang dianggap keliru dan menyesatkan.17

\section{Hasil Dan Pembahasan}

Bagian ini akan penulis gunakan untuk mendeskripsikan pandangan-pandangan SY dan GNS sekaligus mengevaluasinya. Untuk pertama kali, penulis akan memberikan analisis singkat tentang penggunaan nama di dalam Perjanjian Lama.

\section{Pentingnya Nama}

Nama, satu kata sarat makna. Nama menjadi sebuah identitas yang menentukan sesuatu sebagai sesuatu dan seseorang sebagai seseorang. Di dalam Perjanjian Lama, akar kata untuk "nama" dalam bahasa Ibrani adalah šēm (nama), semula dapat berarti "tanda" atau "markah yang membedakan" yang berpadanan dengan kata onoma dalam bahasa Yunani. Dengan demikian, nama dapat menjadi tanda bagi yang menyandangnya. Memberikan ciri khas dan mewakili nilai diri. Dunia zaman kuno menekankan bawah

16Sonny Eli Zaluchu, "Strategi Penelitian Kualitatif dan Kuantitatif Di Dalam Penelitian Agama," Evangelikal: Jurnal Teologi Injili dan Pembinaan Warga Jemaat 4, no. 1 (2020): 28-38; band. Stevri Indra Lumintang dan Danik Astuti Lumintang, Theologia Penelitian Dan Penelitian Theologis ScienceAscience Serta Metodologinya (Jakarta: Geneva Insani Indonesia, 2016).

17Rahmiati Tanudjaja, “Apologetika Kristen: Tanggung Jawab Semua Anak Tuhan,” VERITAS 6/2 (Oktober 2005): 229; band. Yonathan Wijaya Lo, "Natur dan Peran Rasio dalam Apologetika Kristen," Pengarah: Jurnal Teologi Kristen 1, no.1 (Januari 2019): 73-74. 
nama itu menjadi sangat personal karena menyatakan identitas secara aktual dan transparan.18

Dalam narasi penciptaan, Allah menamai ciptaan-Nya dan ciptaan-Nya menamai sesama ciptaan. Allah tidak hanya memberikan mandat kepada manusia untuk beranakcucu, memelihara bumi, dan mengupayakan kesejateraan mereka melainkan juga menyerahkan sepenuhnya tugas dan tanggung jawab untuk menamai. Allah memberikan kesempatan kepada manusia untuk berpikir secara mandiri tentang nama. Nama yang tepat untuk setiap hewan dan tumbuhan yang ada di bumi (Kej. 2:19). Tidak hanya itu, manusia (Adam) pun secara aklamasi menunjukan otorisasinya dalam menamai pendamping hidupnya (Kej. 2:23; 3:20) dan keturunan yang ia hasilkan (Kej. 4:1-2; 5:3). Manusia yang beroleh akal budi itu, kemudian mampu menentukan, memilih, dan memberikan nama kepada sesuatu atau seseorang. Memberikan identitas berupa nama sudah menjadi tugas awal manusia yang penting untuk dilakukan.

Identitas ini tentu dimengerti dalam bahasa manusia. Bahasa yang manusia gunakan, yang kemudian diterapkan dalam pemberian nama. Dengan nama itu, harimau dapat diklasifikasikan sebagai harimau, durian dapat disebut sebagai durian, dan lain sebagainya. Dengan nama itu juga, Allah dapat memanggil manusia dan manusia dapat mengerti bahwa dirinya yang dipanggil. Selanjutnya, manusia dapat memanggil, mengenal, dan memahami sesamanya. ${ }^{19}$

Akan tetapi, dalam penciptaan itu manusia tidak pernah diberikan mandat untuk memberi nama Allah mereka. Ini hal yang menarik. Allah menamakan setiap ciptaanNya dan berkendak agar manusia menamai ciptaan lain dan atau keturunannya dengan lebih spesifik. Namun tidak sedikit pun menugaskan manusia untuk memilih, menentukan, dan menamai Allah.

Apakah Allah tidak memiliki keinginan untuk dikenal manusia dengan sebuah nama? Mengapa Ia tidak menyatakan nama-Nya pada awal penciptaan ini? Apakah nama bagi diri-Nya sendiri adalah tidak penting? Apakah Allah sedang berupaya menyembunyikan nama-Nya? Apakah belum saatnya Allah menyatakan siapa namaNya? Atau, bagi Allah kehadiran dan keberadaan-Nya jauh lebih penting dari pada sebuah nama?

Pertanyaan-pertanyaan yang muncul ini, berkaitan erat dengan cara bagaimana manusia memanggil-Nya. Saat manusia telah menamai hewan, tumbuhan, dan keturunannya, kini manusia harus tahu siapa nama penciptanya. Nama yang dapat dipakainya untuk berseru kepada Allahnya. Nama yang penting baginya untuk tahu pribadi penciptanya.

Menarik untuk disimak. Dalam narasi-narasi yang terdapat di kitab Kejadian, 2012), 110

${ }^{18}$ Herman Bavinck, Dogmatika Reformed - Jilid 2: Allah dan Penciptaan (Surabaya: Momentum,

${ }^{19}$ Band. Elmer L. Towns, Nama-Nama Allah (Yogyakarta: ANDI Offset, 2008), 17. 
tidak satu pun ditemukan pertanyaan tentang nama Allah. Adam, Nuh, Abraham, Ishak, Yakub, Yusuf dan saudara-saudarannya tidak pernah secara gamblang mempertanyakan nama Sesembahan mereka itu. Meskipun mereka mengenal, menyembah serta percaya akan keberadaan dan kemahakuasaan-Nya, namun tidak satu pun dari narasi-narasi itu menjelaskan bagaimana cara mereka dapat mengenal siapa nama Allah mereka. Informasi awal hanya dapat ditemukan dalam Kejadian 4:1 dan 26 namun itupun belum cukup menjelaskan bagaimana mereka akhirnya dapat mengetahui dan menyebut nama Allah mereka.

Pertanyaan tentang siapa nama Allah baru ditemukan saat Musa hendak diutus untuk membebaskan bangsa Israel dari perbudakan di Mesir (Kel. 3:13). Di sini, Musa bertanya: “...bagaimana tentang nama-Nya? Apakah yang harus kujawab kepada mereka?" Lalu, apakah pertanyaan ini mengindikasikan adanya keraguan Musa terhadap pribadi dari Allah yang akan mengutusnya? Mengapa kali ini Musa menanyakan siapa nama Allah? Apakah selama ini mereka tidak mengenal nama Allah mereka?

Hal yang perlu diperhatikan dari pertanyaan Musa tersebut adalah meskipun secara umum menanyakan nama seseorang dalam bahasa Ibrani menggunakan kata ganti $\mathrm{Mi}$ atau "siapakah" namun justru ayat ini menuliskan bahwa Musa menggunakan sebutan "bagaimana ( $m a h$ ) tentang Nama-Nya?". Musa seolah-olah menghendaki sebuah jawaban yang dapat menunjukaan esensi dari nama itu. Tidak hanya menyebut inisial nama tetapi lebih kepada apa dan bagaimana makna dari kuasa yang berada di balik Sang Pemilik-nya.

Pertanyaan Musa ini direspons Allah dengan 'Ehyeh 'Asyer 'Ehyeh (Keluaran 3:14). ${ }^{20}$ Jawaban ini kemudian menjadi sebuah penyataan fenomenom dalam sejarah umat Israel bahkan menggema hingga kini. Setelah sekian lama, Allah baru menyatakan nama-Nya secara gamblang kepada Musa dan bangsa Israel. Nama yang menyatakan pribadi dan keberadaan-Nya. Dalam hal ini, Allah menegaskan kembali kepada bangsa Israel tentang eksistensi, penyertaan, pertolongan, dan pemeliharaan-Nya kepada bangsa Israel. Meneguhkan janji yang telah diberikan kepada Abraham dan keturunanNya.

hwhy (YHWH) atau 'Ehyeh 'Asyer 'Ehyeh dapat diartikan sebagai I am who I am atau "Aku ada yang Aku ada".21 Dikenal dengan istilah Tetragrammaton (nama suci

${ }^{20}$ Band. Martin Steven Lumingkewas, "El \& YAHWEH (Allah Israel)," OSF Preprints (24 Maret 2020), Web.: 74.

${ }^{21}$ LAI menerjemahkannya sebagai "Aku adalah Aku". Menurut penulis, terjemahan ini kurang tepat sebab jika terjemahan itu seharusnya tertulis "Anokhi hayah Anokhi". Kata Ehyeh yang berasal dari akar kata Hayah adalah kata kerja imperfek yang menyatakan sesuatu yang sedang berlangsung atau belum selesai. Kata Hayah sendiri dalam Perjanjian Lama dapat diterjemahkan dengan beberapa opsi, yaitu: 1) "Exist, be Present" (Ada, Hadir), 2) Come into Being (menjadi), atau sebagai 3) Auxilaries Verb (kata kerja bantú), lih.: G. Johanes Boterweck dan Helmer Ringren, Theological Dictionary of The Old Testament, Vol III (U.S.A.: Grand Rapids Michigan, 1978), 373; band. J. Douma, The Ten Commandments Manual for the Christian Life (U.S.A.: P\&R Publishing Company, 1996), 76; Herman Bavinck, Dogmatika 
empat huruf). Nama yang memberikan paparan tentang keagungan dan esensi diri Allah dan dipandang oleh bangsa Yahudi sebagai nama yang terutama. ${ }^{22}$ Berkhof bahkan berpendapat bahwa nama ini sangat sakral dan paling diagungkan dari semua nama lain di bangsa Israel. ${ }^{23}$ Sedemikian sakral hingga akhirnya melahirkan sebuah aliran yang gigih mempertahankan penggunaan nama tersebut dalam iman dan ibadah mereka serta mengkritisi semua nama lain yang digunakan oleh orang Kristen dan Alkitab. Pada pembahasan berikut ini, penulis akan menelaah pandangan ini.

\section{Menyelesaikan Polemik}

Presaposisi yang dibangun oleh SY dan GNS perlu mendapat perhatian yang komprehensif. Dalam hal ini, penulis akan memaparkan teori-teori yang menyakralkan penyebutan Tetragramaton sekaligus berupaya menawarkan ulasan-ulasan yang kritis dan evaluatif terhadap teori-teori tersebut.

Hal pertama yang perlu diperjelas dan ditekankan dalam penelitian ini adalah bukan manusia yang menamai Allah. Nama yang Allah gunakan untuk menyatakan diriNya tidak bersifat arbiter. Dengan kata lain, Allah tidak menentukan nama-Nya berdasarkan negosiasi aktif maupun pasif dengan manusia. Meskipun Allah menggunakan bahasa manusia dan bukan ilahi. Dengan nama-Nya, Allah menyatakan diri dan berelasi dengan ciptaan-ciptaan-Nya. Manusia dapat memanggil-Nya dengan semua nama yang dinyatakan oleh Allah, sebagai sebutan-sebutan Allah. Saat menyebut nama-nama itu, ada keharusan untuk menjaga kekudusan dan kemuliaan-Nya. ${ }^{24}$

Oleh karena Allah menyatakan nama-Nya dengan menggunakan bahasa manusia yang terbatas (finit), jelas kontras dengan kekekalan kesempurnaan (infinit) Allah. Bavinck berpendapat: "Seandainya Allah berbicara kepada kita dalam bahasa ilahi, tidak satu pun ciptaan yang akan memahami Dia."25 Memahami segala kepenuhan Allah yang tidak terbatas melalui bahasa manusia yang terbatas dan berkesudahan adalah upaya yang mencoba melanggar keberadaan-Nya itu sendiri. Jika demikian, maka menyebut dan atau memanggil Allah dengan nama apa pun jelas merupakan tindakan penistaan terhadap keagungan Allah yang infinit itu. Dalam hal ini, Allah tidak dapat dan tidak boleh disebut atau dipanggil dengan nama apa pun. ${ }^{26}$

Implikasi logis dari pemahaman ini adalah setiap nama, baik itu Yahweh, Elohim, Adonay, Kurios, Theos, Allah, dan lainnya merupakan nama yang dipakai Allah secara antropomorfis. Jika nama-nama itu hanya merujuk pada persoalan "nama" dan bukan pada pribadi dan relasi-Nya dengan ciptaan, maka semua upaya manusia untuk

Reformed - Jilid 2: Allah dan Penciptaan, 169; Herlianto, Gerakan Nama Suci - Nama Allah yang Dipermasalahkan, 92.

${ }^{22}$ Herman Bavinck. Ibid, 166.

${ }^{23}$ Louis Berkhof, Teologi Sistematika 1 - Doktrin Allah, Cetakan ketiga (Jakarta: LRII, 1997), 71.

${ }^{24}$ Herman Bavinck, Ibid,113.

25Ibid.

26Ibid, 120. 
memanggil-Nya merupakan bentuk penistaan terhadap eksistensi kekekalan-Nya. Tetapi tidak demikian. Allah berkenan menyatakan diri-Nya dengan bahasa yang dimengerti manusia.

Kedua, Alkitab dilatarbelakangi oleh budaya Yahudi. Hal ini sekaligus memberikan informasi bahwa pemaknaan pada 'nama' harus dimengerti dalam konteks Yahudi. Bagi orang Yahudi, sebuah 'nama' memiliki keterkaitan yang sangat erat dengan 'pribadi'. Makna nama di dalam Kitab Suci dapat merujuk pada pribadi itu sendiri, mengungkapkan pribadi dari nama itu, dan nama dapat menyatakan kehadiran yang aktif dari pribadi peyandang nama tersebut. ${ }^{27}$ Lalu, bagaimana jika ketiga hal ini diterapkan pada Allah? Mari perhatikan dengan saksama.

Nama Allah menunjuk kepada pribadi Allah itu sendiri. Alkitab sendiri sering mengaitkan eksistensi seseorang dengan nama dari orang tersebut. Jika orang tersebut tiada, maka nama orang tersebut juga dinyatakan lenyap. Contoh yang paling jelas seperti terdapat di dalam Yosua 7:9: “...maka mereka akan mengepung kami dan melenyapkan nama kami dari bumi ini. Dan apakah yang akan Kau lakukan untuk memulihkan Nama-Mu yang besar itu?" Begitu juga ketika Allah diidentikan dengan Sang Nama. Misalnya dai dalam Imamat 24:11: "anak perempuan Israel itu menghujat TUHAN dengan mengutuk..." (baca: Wayyiqov ben ha'isyah ha yisreelit et hasyem]). Kata TUHAN di sini diterjemahkan dari kata "ha syem" yang sebenarnya dapat di artikan Sang Nama.

Ini menunjukan bahwa nama dalam Alkitab tidak sekadar memiliki implikasi makna pada nama yang disebutkan tapi menunjuk kepada pribadi yang memiliki nama tersebut. Dalam hal ini, pengagungan tersebut tidak seharusnya dititikberatkan pada nama Yahweh itu melainkan pada pribadi Allah itu sendiri. ${ }^{28}$

Nama juga mengungkapkan jati diri dari pemilik nama itu. ${ }^{29}$ Satu contoh ayat

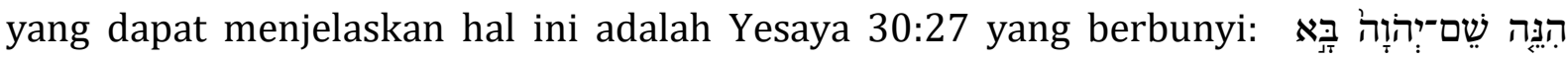

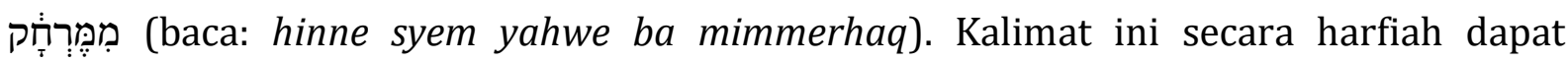
diterjemahkan: "Lihatlah, Nama TUHAN datang dari tempatNya yang jauh." Pertanyaannya, mengapa tidak dikatakan TUHAN yang datang tetapi Nama TUHAN yang datang? Apakah sebenarnya yang hendak dinyatakan di sini? Tentu saja ayat ini memberikan aksentuasi pada penyingkapan pribadi dari TUHAN. Dalam hal ini, terjemahan yang terdapat di dalam Alkitab Terjemahan Baru LAI sudah tepat dengan mengartikan שָׁם:יְוזה sebagai "menyatakan diri-Nya." Sekali lagi ini dapat mendukung pembuktian bahwa penekanan SY dan GNS tentang keharusan penyebutan harfiah dari nama Yahweh.

\footnotetext{
27Ensiklopedi Alkitab Masa Kini, Jilid 2.

28Ibid

29Ibid
} 
Selain itu, nama di dalam Alkitab menyatakan pula keadaan dan kehadiran yang aktif dari Pribadi pemilik nama itu. ${ }^{30}$ Kisah penantangan nabi Elia kepada nabi-nabi baal di gunung Karmel dapat dijadikan contoh untuk bagian ini. Elia sendiri memberikan tantangan kepada para nabi tersebut untuk menunjukan manakah nama ilah yang lebih berkuasa dan sesungguhnya adalah Allah (1Raja. 18:24). Pada konteks ini Allah yang

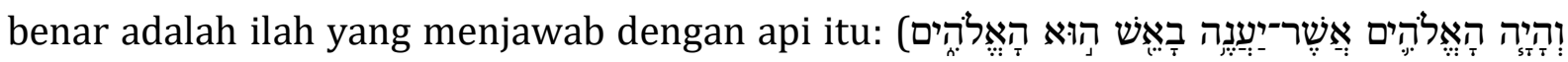
[baca: we hayah ha elohim asyer yaeneh be esh hu ha elohim]). Dari ayat ini juga dapat disimak bahwa kata "Allah" bukan merupakan nama diri (the proper name). Nama diri Allah adalah Yahwe yang muncul sebagai pemenang sebab Dia merupakan Pribadi yang hadir secara aktif dan nyata.

Jika menelisik gramatikal dari kata YHWH sendiri, jelas bahwa kata ini sangat berkaitan dengan pribadi Allah yang Maha hadir, baik saat lampau, kini, dan akan datang. Aspek-aspek waktu kemahahadiran Allah ini berkaitan dengan gramatikal bahasa Ibrani. Kata "hayah" (Dia telah ada), "howeh" (Dia ada), dan "yihyeh" (Dia akan ada). Dengan demikian, kata Yahweh menunjuk kepada Allah yang hadir secara aktif dalam segala zaman.

Akan tetapi yang perlu ditekankan di sini adalah bahwa kekristenan pada umumnya sepakat bahwa nama Yahweh merupakan "nama diri" Allah. Hanya menurut penulis, dalam penerjemahan, LAI tetap meneruskan tardisi sejak masa Yesus, para murid-Nya, dan gereja mula-mula bahwa meskipun nama Yahweh tetap dipertahankan dalam teks bahasa asli Kitab Suci Perjanjian Lama, namun nama ilahi itu tidak harus diterjemahkan demikian. Hal ini sekaligus membuktikan bahwa nama YHWH/Yahweh sebenarnya dapat diterjemahkan ke dalam berbagai bahasa, seperti misalnya yang dilakukan oleh para penerjemah Septuaginta, termasuk yang para penulis kitab-kitab Perjanjian Baru yang tidak lagi berpatokan kepada keharusn menggunakan nama Yahweh sebab yang terpenting bukanlah bentuk nama melainkan pribadi dari nama itu.

Ketiga, mempertahankan nama Yahweh dengan tujuan mendapatkan keselamatan adalah suatu kesesatan. Mengutip ayat-ayat Alkitab secara lepas dan memberikan penekanan religius terhadap pemakaian nama Yahweh adalah langkah yang keliru. Upaya legalistik ini tentu sangat bertentangan dengan Alkitab. Mengapa? Karena jelas hal ini menunjuk pada doktrin keselamatan karena perbuatan baik: keharusan mengucapkan nama Yahweh dengan benar dan tepat agar diselamatkan. Efesus 2:8-9 dengan tegas menyatakan, "Sebab karena kasih karunia kamu diselamatkan oleh iman; itu bukan hasil usahamu, tetapi pemberian Allah, itu bukan hasil pekerjaanmu: jangan ada orang yang memegahkan diri."

Keempat, Gerakan Nama Suci pada prinsipnya juga tidak konsisten. Gerakan ini bukan merupakan sebuah gerakan yang bersifat tunggal tetapi bervariasi. Oleh sebab itu, tidak mengherankan jika gerakan ini memiliki banyak ketidaksamaan konsep 
perihal penyebutan nama Yahweh. Sangat ironis, karena gerakan ini dengan radikal memberikan penekanan penyebutan nama YHWH dengan BENAR dan TEPAT tetapi memiliki penyebutan nama yang bervariatif. L.D. Snow memberikan gambaran yang menarik tentang fenomena ini. Ia berpendapat bahwa para penganut gerakan ini tidak memiliki rumusan yang tetap mengenai pelafalan nama YHWH. Ada yang menyebutnya IHVH, JHVH, JHWH, YHVH, YHWH, JAHAVEH, JAHVAH, JAHVE, JAHVEH, YAHVE, YAHVEH, YAHWE, dan YAHWEH. ${ }^{31}$ Mana yang benar? Manakah dari para penganut gerakan ini yang akan diselamatkan? Jika teori yang dikumandangkan oleh gerakan ini benar, maka keberagaman ini tentu saja menempatkan para penganutnya dalam posisi yang juga salah karena tidak memiliki sebutan yang BENAR dan TEPAT. Dengan kata lain, para pengagum nama suci ini sedang menyerang (argumen) diri sendiri (strawmen fallacious) ketika mengeritik kekristenan.

Kelima, tindakan menyalahkan para penerjemah Septuaginta adalah keliru. Dalam LXX, kata "Yahweh" diterjemahkan menjadi "Kurios" yang berarti "Tuhan". Penerjemahan ini dipandang oleh GNS salah dan sesat. Nama Yahweh adalah nama pribadi yang tidak bisa digantikan oleh kata Kurios yang adalah nama dewa Yunani. ${ }^{32}$ Para penganut ini berpendapat bahwa semasa Yesus dan para murid hidup, mereka tetap menggunakan nama Yahweh. Hal ini juga dibuktikan dengan adanya naskah (septuaginta) Paleo Hebrew yang tetap mencantumkan nama Yahweh itu. ${ }^{33}$ Hal ini jelas merupakan langkah predisposisi yang dilakukan oleh pengikut GNS. Bagaimana mungkin menutup mata terhadap begitu banyaknya naskah LXX dan versi-versi terjemahan lainnya yang tidak mencantumkan nama Yahweh? Lalu menganggap bahwa naskah LXX dan versi terjemahan yang lain tidaklah benar? Apa standar otorisasinya? Apakah hanya karena nama Yahweh? Dalam hal ini, para pengikut GNS kedapatan menggunakan standar ganda untuk membenarkan argumen mereka. Di samping itu, teks dari naskah Paleo Hebrew yang mencantumkan Tetragramaton itu dianggap sebagai sisipan. Terlihat dari perbedaan besarnya ukuran huruf dengan kata-kata lain, perbedaan gaya penulisan, kepekatan tinta, terlihat ada bayang-bayang kata yang telah dihapus di belakang nama YHWH itu, dan perbedaan dalam jarak antar kata.

Keenam, pandangan bahwa nama Yahweh dianggap telah dikenal jauh sebelum masa Musa yaitu pada dunia kafir untuk mendukung argumen penolakan terhadap keharusan menggunakan nama Yahweh pun merupakan kesimpulan yang gegabah. Misalnya, Herlianto berpendapat bahwa nama Yahweh bukan nama yang baru dikenal Musa dalam peristiwa di gunung Horeb tetapi diduga memiliki asal muasal dari kaum

${ }^{31}$ L.D. Snow, "A Brief Histori of the (Sacred) Name Movement in America," World Today Analyzed (September 1975), dikutip dalam Herlianto, Ibid, 15.

32Budi Asali, "Keharusan Menggunakan Nama Yahweh dan Larangan Menggunakan Kata Allah" (ceramah, G.K.R.I Golgota: Surabaya, 6 Juni 2008).

${ }^{33}$ Jahja Iskandar, "Mengapa Nama Yahweh Semakin Populer." (Jakarta: PT Abiyah Pratama, 2009): 86-87, dikutip dalam Oky Otto Otto, Ibid, 35. 
Keni-Midian. ${ }^{34}$ Atau, pendapat dari Hartmann, Bohlen, Colenso, Dozy, dan Land bahwa nama itu berasal dari Kanaan atau Funisia dan akhirnya digunakan oleh bangsa Israel yang masuk ke tanah Kanaan. ${ }^{35}$ Menjawab hal ini, penulis sependapat dengan Bavinck yang menyatakan bahwa pendapat-pendapat tersebut tidak dapat dibuktikan dan dipertahankan sebab tidak ada jejak yang ditemukan tentang suatu allah bangsa Kanaan yang bernama Yahweh. ${ }^{36}$

Bukti-bukti yang penulis paparkan di atas jelas menunjukan bahwa argumentasi yang dibangung oleh para teolog GNS adalah argumentasi yang keliru dan cacat logika. Begitu pula anggapan bahwa nama Yahweh berasal dari dunia kafir juga tidak memiliki dasar pembuktian yang sahih.

\section{Kesimpulan}

Kelompok-kelompok yang memiliki andil dalam polemik ini dipengaruhi oleh semangat Yudaisme. Baik Saksi Yehuwa maupun Gerakan Nama Suci berangkat dari pemahaman yang sama mengenai pengembalian akar-akar yudaik. Penekanan tentang pentingnya penyebutan nama YHWH bagi kekristenan sebenarnya bukanlah suatu persoalan. Itu benar adanya. Akan tetapi, keharusan menyebutnya sebagai syarat keselamatan telah melenceng jauh dari konteks pemahaman Alkitab secara menyeluruh. Ini yang salah dari Saksi Yehuwa dan Gerakan Nama Suci. Menghormati nama Tuhan yang mana saja adalah kewajiban setiap orang Kristen. Penekanan yang lebih penting justru harus ditujukan pada pribadi Sang Nama yang berada di balik dan menyandang nama-nama itu. Allah yang telah ada dan akan terus ada menyertai umat-Nya. Allah Abraham, Ishak,Yakub, dan umat yang percaya pada-Nya.

\section{Referensi}

Aritonang, Jan S. Berbagai Aliran di Dalam dan di Sekitar Gereja. Jakarta: BPK Gunung Mulia, 2008.

Bavinck, Herman. Dogmatika Reformed-Jilid 2: Allah dan Penciptaan. Surabaya: Momentum, 2012.

Berkhof, Louis. Teologi Sistematika 1-Doktrin Allah, Cetakan ketiga. Jakarta: LRII, 1997.

Boterweck, G. Johanes dan Helmer Ringren, Theological Dictionary of The Old Testament, Vol III. U.S.A.: Grand Rapids Michigan, 1978.

Budi Asali, "Keharusan Menggunakan Nama Yahweh dan Larangan Menggunakan Kata Allah” (ceramah, G.K.R.I Golgota: Surabaya, 6 Juni 2008).

Clover, R. The Sacred Name, Jilid 1. U.S.A.: Qadesh La YAHWEH Press, 2002.

Douglas, JD., Peny. Ensiklopedi Alkitab Masa Kini, Jilid 2. Jakarta: Yayasan Komunikasi

${ }^{34} \mathrm{Ibid}, 98$.

${ }^{35}$ Herman Bavinck, Ibid, 168

36Ibid. 
Bina Kasih, 1995.

Douma, J. The Ten Commandments-Manual for the Christian Life. U.S.A.: P\&R Publishing Company, 1996.

Fischer, John. Why Messianic Judaism, dalam Enduring Paradoxs (Baltimore: Messianic Jewish Publishers, 2000.

Herlianto. Gerakan Nama Suci -Nama Allah yang Dipermasalahkan. Jakarta: BPK Gunung Mulia, 2009.

Hindarto, Teguh, "Messianic Judaism \& Sacred Name Movement: Fenomena Keagamaan Abad XX dan Tanggapan Kekristenan (Seri 1)," https://pijarpemikiran.blogspot.com (diakses 16 Juni 2020).

Iskandar, Jahja. "Mengapa Nama Yahweh Semakin Populer.” (Jakarta: PT Abiyah Pratama, 2009): 86-87, dikutip dalam Oky Otto Otto, History of YHWH - Tantangan, Argumentasi, dan Pembuktian Sejarah Penggunaan Kata YHWH. Yogyakarta: ANDI, 2013.

Lo, Yonathan Wijaya. "Natur dan Peran Rasio dalam Apologetika Kristen," Pengarah: Jurnal Teologi Kristen 1, no.1 (Januari 2019): 9-22.

Lumingkewas, Martin Steven. "El \& YAHWEH (Allah Israel)," OSF Preprints (24 Maret 2020), Web.

Lumintang, Stevri Indra dan Danik Astuti Lumintang. Theologia Penelitian Dan Penelitian Theologis Science-Ascience Serta Metodologinya. Jakarta: Geneva Insani Indonesia, 2016.

Otto, Oky Otto. History of YHWH - Tantangan, Argumentasi, dan Pembuktian Sejarah Penggunaan Kata YHWH. Yogyakarta: ANDI, 2013.

Shiffman, Michael. Return of the Remnant: the Rebirth of Messianic Judaism. Baltimore: Lederer Messianic Publishers, 1996.

Snow, L.D. "A Brief Histori of the (Sacred) Name Movement in America," World Today Analyzed (September 1975), dikutip dalam Herlianto, Gerakan Nama Suci - Nama Allah yang Dipermasalahkan. Jakarta: BPK Gunung Mulia, 2009.

Stern, David. Messianic Jewish Manifesto. Maryland: Jewish New Testament Publications, 1991.

Tanudjaja, Rahmiati. "Apologetika Kristen: Tanggung Jawab Semua Anak Tuhan," VERITAS 6/2 (Oktober 2005): 229-238.

Towns, Elmer L. Nama-Nama Allah. Yogyakarta: ANDI Offset, 2008.

Watchtower Bible and Tract Society of New York Inc. International Bible Students Association, "Kitab Suci Terjemahan Dunia Baru," Peny. New World Translation of The Holy Scriptures Indonesia" (New York: Watchtower Bible and Tract Society of New York Inc. International Bible Students Association, 1999): 2024, dikutip dalam Oky Otto Otto, History of YHWH-Tantangan, Argumentasi, dan Pembuktian Sejarah Penggunaan Kata YHWH. Yogyakarta: ANDI, 2013. 
Zaluchu, Sonny Eli. "Strategi Penelitian Kualitatif dan Kuantitatif Di Dalam Penelitian Agama," Evangelikal: Jurnal Teologi Injili dan Pembinaan Warga Jemaat 4, no. 1 (2020): 28-38 